\title{
The Effectiveness of Using Films and Documentaries in the EAP Classroom to Teach Contemporary Political Discourse
}

\author{
Kim, Kitai \\ (Hannam University)
}

\begin{abstract}
Kim, Kitai. (2018). The effectiveness of using films and documentaries in the EAP classroom to teach contemporary political discourse. STEM Journal, 19(4), 1-26.

This article examines the effectiveness of using films and documentaries to teach topics related to weapons proliferation as well as the use of small arms and light weapons in the English for academic purposes (EAP) classroom. The use of films and documentaries is intended to supplement the course textbook and lectures to help students improve content knowledge and communicative competence in a course called Contemporary Political Discourse. The study uses the films Charlie Wilson's War and Lord of War to examine the global proliferation of weapons as well as Michael Moore's documentary Bowling for Columbine to examine the issues of small arms and light weapons in America. This study builds on prior research that highlights the difficulties students face when transitioning from high school EFL classes to the conceptually dense prose in EAP content courses at the university level. The study presents methods of utilizing documentary and films to teach the course material using film clips, film scripts, and class discussions. Based on the results of student surveys, the study concludes that films are an effective resource to teach content as well as improve communicative competence for students who are unaccustomed to an EAP setting in a global program in Korea.
\end{abstract}

\section{INTRODUCTION}

This article examines the effectiveness of using films and documentaries to improve content knowledge and communicative competence in a course called Contemporary Political Discourse. The course is part of an undergraduate degree program offered in English at a global college in Korea ${ }^{1}$. The program is taught by an international faculty and students are expected to use English both in and outside of the classroom. Though

\footnotetext{
1 The global program is part of a university in the central region of Korea with approximately 12,250 undergraduates. The global program has approximately 400 students.
} 
many students perform well academically in the program, there are still many others who struggle to comprehend the difficult and often dense prose contained in course textbooks. As universities and colleges in Korea face difficulties fulfilling their enrollment quotas, they are at times likely to admit students who are not qualified in terms of academic achievement or language proficiency. Many of these students lack the necessary competency in English to comprehend the course material and struggle academically during their time in the program. As a result, these students begin their academic studies unable to keep pace with more advanced level students. In such cases, the use of film to supplement the course textbook is an effective method to assist students improve their content knowledge.

There have been several studies in the field of English literature in Korea to assist students improve comprehension of course content using film in the classroom (Choi, 2007; Kim, 2003; Lee, 2001; Shin, 2000; Sung, 2000; Yim, 2004). However, these studies mainly focused on comparing and analyzing literary works and films in order to analyze to what extent the films deal with the content and theme of literary works. For instance, Choi (2007) conducted a study regarding the use of film by comparing the literary text of The Great Gatsby (Fitzgerald, 2018) with its film adaptations in a course related to British and American literature and film. Students were required to examine the original text and compare it with the film scenes in order to distinguish differences between the two. Although the study concluded that using film was useful in developing students' understanding of British and American literature and culture, it did not provide data or results of how the students' comprehension of the contents was improved.

In addition to the field of English literature, there are many studies in various disciplines using film to teach content (Centellas, 2010; Engert \& Spencer, 2009; Goldenberg, Lee, \& O'Bannon, 2010; Kim, 2013; Kim, 2016; Koch \& Dollarhide, 2000; Kuzma \& Haney, 2001; Macy \& Terry, 2008; Muller, 2006; Pescosolido, 1990; Pino, Brunson, \& Stewart, 2009; Seo, 2016; Stoddard \& Marcus, 2010; Swimelar, 2013; Waalkes, 2003; Weber, 2001). The majority of the studies focused on providing evidence of increased students' interest and learning motivation rather than on increasing content knowledge or communicative competence. Therefore, different from previous research, this study focuses on the effectiveness of using films to enhance students' content knowledge and communicative competence in the EAP classroom.

This study uses selected scenes and scripts from two films to supplement course content related to the proliferation of weapons and the global arms trade. Likewise, scenes and scripts from a documentary are also used to illustrate the issue of small arms and light weapons. The use of scenes and scripts is intended to provide students with a frame of reference on which to place course material and information in order to help students understand the key terms and complex issues rather than by just reading the textbook and 
listening to the lectures. To improve comprehension skills, the study also utilizes strategies suggested by Lei, Rhinehart, Howard, and Cho (2010) to conduct class discussions related to the subject matter in order to activate students' background knowledge and experience. This strategy is utilized and incorporated into the methodology of this paper.

Accordingly, the study aims to show the benefits of using both the film and film script to help students better comprehend the course textbook and to improve communicative competence in the subject matter. To accomplish this objective, the study employed a questionnaire survey examining three aspects related to the use of films in regard to students' perceptions, improvement of communicative competence, and students' satisfaction regarding the use of film. It is hoped that the findings of this study will contribute to the growing body of research that verifies the effectiveness of using films in the EAP classroom to teach content. Specifically, the research questions for this study are:

1. What are the students' perceptions regarding the use of films in the EAP classroom?

2. What improvements in communicative competence are there in regard to the use of films in the EAP classroom?

3. How satisfied are students using films in the EAP classroom?

\section{LITERATURE REIVEW}

Though there are many studies related to the use of film in the classroom, this study gives priority to previous research that show the merits of using films and documentaries in order to teach content as well as increase students' interests and motivation in the EAP classroom. A review of the literature reveals many studies that utilize film, videos, and/or television programs to teach and supplement course material in various majors and disciplines. Many of the studies reported that the use of films was effective in teaching content and that it increased students' interest and participation in the class.

In courses related to the humanities, Muller (2006) used movies to help students visualize literary theory related to Dark Romanticism, archetypal theory, and deconstruction. The article presents the thesis that multimedia texts are commonly available to students and that the use of films as an art form can help students improve their comprehension of literary theories. Kim (2013) used films to teach aspects related to the study of literature such as symbolism, literary adaptation, and the Byronic Hero in addition to using films to teach cultural theory related to post-structuralism (Kim, 2016). Seo (2016) used films to improve communicative competence by using them as authentic resources to teach history related to stolen art collections owned by Austrian Jews during 
the Second World War. As well, Stoddard and Marcus (2010) used films to teach history in high schools. The study attempts to address the tendency of society to learn history from films and television programs and how the general public therefore needs to be educated in order to critically view and analyze what they watch. Using films to present aspect of social studies pedagogy and past research, the authors try to teach viewers how to be more media literate.

Films are also used in courses related to the social sciences. Goldenberg et al. (2010) used movies as teaching tools to enhance recreation, parks, and tourism courses. The authors provide instructions on the use of seventy-seven movies and how they can be used to teach content related to their major. Koch and Dollarhide (2000) used films as a teaching tool in counselor theories and education. The study concludes that films helped students' improve their comprehension and application of course concepts as well as improve the instructor's relationship with the class. Macy and Terry (2008) used movies as a vehicle for critical thinking in economics and business courses. The study focuses on various methods to teach concepts related to business ethics and new teaching methods related to economic theory instead of the traditional "chalk and talk" presentation style commonly used by economics professors. By examining the plots and ethical dilemmas presented in the films, students were more interested in and willing to participate in class discussions. Pescosolido (1990) used films to teach theoretical and practical aspects related to medical sociology. The study uses films as case studies related to mental illness, death-dying, and the political economy of illness in order to present a new method of teaching that will improve active participation as well as incorporate current student's high visual literacy. Pino et al. (2009) used movies to illustrate ethical dilemmas in criminal justice classes. Using a control and experimental group, the study used films to teach ethics for the purpose of helping students retain what they learned after graduation and into their professional careers. The experimental group using films was more likely to better understand the complexities of ethical dilemmas, rate unethical behavior, and determine how ethical principles are applied in society.

Moreover, there are many studies using films to teach subjects related to political science and international relations. Centellas (2010) used the television program American Idol to teach the works of Karl Marx and Alexis de Tocqueville and how they relate to political science and pop culture. Using the show as a base, students were required to write arguments projecting Marx's or Tocqueville's ideological positions of American Idol. By using a cultural text from popular culture that students are familiar with, the study concluded that it helps students better understand the ideals and differences of Marx and Tocqueville while developing and improving their critical thinking and analytical skills. Engert and Spencer (2009) used films to teach topics related to international relations and politics and to debate specific issues such as terrorism and genocide. Kuzma and Haney 
(2001) used films to teach foreign policy to political science and international relations majors. The study revealed that films helped students understand new and abstract concepts and theories and trained them to be more critical of political issues in films that they did not notice before. Swimelar (2013) used films to help students visualize aspects related to international relations. Building on past research, the study focuses on the use of films to teach aspects related to political theory, the media, and human rights. Waalkes (2003) used films to teach the rise and "decline" of nation-states in political science courses. Using films helped students discuss topics related to the rise of the state and the possible reasons for their decline. Using film clips improved students' critical thinking regarding comparative politics and constructivist scholarship. The study noted that an additional benefit of using films was the additional preparation and effort required to use films in the classroom by instructors. Lastly, Weber (2001) used films to teach IR theory for theoretical critique. The study attempts to utilize and activate students' background knowledge and visual analytical skills that they already possess and transfers them to analyze IR theories and international politics.

Though these studies highlight the effectiveness of using films to teach content in the classroom there is still debate about the relative value of using films. Scholars (Sealey, 2008) who are skeptical of the use of film, music or pop culture in the classroom are challenged by others who note the positive benefits for students stating, "[Film] stimulates the senses, grounds abstract concepts, engages the emotions, contextualizes history, and facilitates an active-learning classroom environment (Kuzma \& Haney, 2001, p. 34). Scholars also note the increased participation that results from the use of films:

[The] visualization of abstract concepts or historical events may be more captivating for students than just reading about them; moreover, because film is already a familiar medium for students, it breaks down some teacher-student barriers and may encourage students to be more active participants in the class.

(Swimelar, 2013, p. 3)

However, the most beneficial aspect of using film is the ability to increase students' comprehension of abstract theories and concepts related to course materials (Engert \& Spencer, 2009; Sealey, 2008; Waalkes, 2003; Weber, 2001). These studies affirm that films are an effective resource to teach content in the EAP classroom. As Shih (1992) and Kim (2016) note, many non-native English speakers have difficulty transitioning from the short varied reading of ESL or EFL readings to the abstract and complex writings of course textbooks. Though the above studies highlight creative and effective methods of using films to teach content, there are few studies that examine the use of films to teach content in the EAP classroom in Korea. 


\section{RESEARCH DESIGN}

\section{Participants}

The participants of this study were undergraduate students $(n=34)$ majoring in global business between the ages of 18-28. The students were second to fourth year students with self-assessing English proficiency levels ranging from intermediate to advanced high. While six of the students never lived abroad, many of the students lived from one to ten years in a foreign country. Four students lived abroad for more than 10 years. See Table 1 regarding the demographic information of respondents.

TABLE 1

Demographic Information of Respondents

\begin{tabular}{lccc}
\hline \multirow{2}{*}{ Items } & Variables & Responses \\
\cline { 3 - 4 } & & 0 & Rate (\%) \\
\hline 1. Grade & 1 & 2 & $0 \%$ \\
& 2 & 6 & $5.9 \%$ \\
& 3 & 26 & $17.6 \%$ \\
& 4 & 14 & $76.5 \%$ \\
\hline 2. Gender & Male & 20 & $41.2 \%$ \\
& Female & 0 & $58.8 \%$ \\
\hline 3. English Proficiency Level & Beginning & 6 & $0 \%$ \\
& Intermediate & 20 & $17.7 \%$ \\
& Advanced & 8 & $58.8 \%$ \\
& Advanced High & 6 & $23.5 \%$ \\
\hline 4. Years of Living Abroad & None & 6 & $17.6 \%$ \\
& $1-3$ years & 10 & $17.6 \%$ \\
& $3-5$ years & 8 & $29.5 \%$ \\
& $5-10$ years & 4 & $23.5 \%$ \\
& Above 10 years & & $11.8 \%$ \\
\hline
\end{tabular}

\section{Material}

Contemporary Political Discourse is a major elective course that is part of the global business curriculum. The course covers subjects related to political science, human rights, international relations, globalization, economics, global trade, history, and weapons proliferation. Because there are no prerequisites for the course, students often do not have the necessary background nor information related to key terms in order to comprehend and analyze the topics and issues addressed in the textbook. In this situation, the instructor must find supplemental methods to facilitate comprehension of the material presented in 
the textbook. The use of films and documentaries related to the subject matter can provide instructors with a valuable tool to help students with their reading comprehension of the text as well as improve their communicative competence related to the subject.

One of the objectives of Contemporary Political Discourse is to examine the economic, political, financial, environmental, criminal, cultural and military aspects of how globalization affects society and how these areas are all intricately linked together in an increasingly complex world. One aspect of military globalization is the proliferation of weapons. There are several events and developments in modern history regarding military globalization.

1. The competition among European powers and territorial expansion that resulted in the colonization of Asia, Africa, and the Americas;

2. The emergence of international alliances and international security regimes, such as the Concert of Europe and the North Atlantic Treaty Organization (NATO);

3. The proliferation of weapons and military technologies worldwide; and

4. The creation of global institutions to deal with military issues, such as the nuclear nonproliferation regime. (Payne, 2010, p. 17)

The textbook for the course, Global Issues (Payne, 2010), provides sufficient historical analyses and details regarding all of the above points with the exception of the proliferation of weapons and military technologies. The text provides few details and explanations regarding this topic. To remedy this situation, the use of films and documentaries related to the subject matter was used to supplement the textbook in order to provide background information. The films can also be used to highlight the economic, political, and cultural reasons for the proliferation of weapons. Each of the films and the documentaries deal with specific aspects of the arms trade, arms trafficking, and the proliferation of weapons on a national and global level.

Lord of War (Niccol \& Cage, 2005) is a film about the global selling and trading of small arms and light weapons. The main character, Yuri Orlov is loosely based on the former Soviet Air Force officer Viktor Bout, who became known as the "Merchant of Death" for running an international arms trafficking network. Like Lord of War, Charlie Wilson's War (Nichols \& Hanks, 2007) is also a film based on actual events and people. The film describes the covert efforts of Congressman Charles "Charlie" Wilson who wants to help the Afghanistan rebels, the Mujahedeen, in their struggle against the Soviet aggressors. With assistance from CIA operative Gust Avrakotos and Joanne Herring, an ultra-right wing activist, Wilson develops a plan to help the mujahedeen. Bowling for Columbine (Moore, 2002), is an American documentary by Michael Moore about the 1999 
Columbine High School massacre. Moore attempts to examine why the massacre occurred and why violent crimes related to the use of firearms is higher in the United States than those of other nations. Moore attempts to analyze a number of issues in the film but most importantly, he tries to explore the issue of gun control and gun use in America.

\section{Data Collection}

In order to determine the effectiveness of using films and documentaries in the EAP classroom to teach content related to guns, gun control, and weapons proliferation, a survey questionnaire including eighteen questions was offered online to students through Google Docs in August 2018 (see Appendix A). The students had taken Contemporary Political Discourse during the second semesters of $2015(n=15)$ and $2016(n=19)$. The survey included a variety of question types in the form of a 5-point Likert scale ranging from "Strongly Disagree" to "Strongly Agree." The eighteen questions were grouped according to the themes of student's perception on the effectiveness of using film, their improvement in regard to communicative competence, and satisfaction with the use of films in the EAP classroom.

As the online survey was administered through Google Docs, it automatically collated the data as a spreadsheet. The results were arranged according to the responses of the participants to the Likert scale and multiple-choice questions. The results of Cronbach's Alpha reliability analysis Table 2, revealed an Alpha coefficient of .76 in regard to student's perceptions regarding the use of films. The Alpha coefficient regarding improvement of communicative competence was .92 and students' satisfaction using films was .86 . The figures prove that the questionnaire has high internal consistency and that the questionnaire is highly reliable.

TABLE 2

Reliability of Responses

\begin{tabular}{cccc}
\hline \hline Theme of the Questions & $\begin{array}{c}\text { Cronbach's } \\
\text { Alpha }\end{array}$ & $\begin{array}{c}\text { Number of } \\
\text { Question }\end{array}$ & $\begin{array}{c}\text { Number of } \\
\text { Items }\end{array}$ \\
\hline Students' perception & .76 & Q1 Q3 & 3 \\
Improvement of communicative competence & .92 & Q4 Q15 & 12 \\
Students' satisfaction & .86 & Q16 Q18 & 3 \\
\hline
\end{tabular}

\section{Procedure}

The procedures for using films and documentaries to supplement the textbook in order to improve content knowledge as well as communicative competence begin with the viewing of the films. Prior to beginning the chapter on small arms, light weapons, and 
weapons proliferation, students were instructed to watch the three films outside of class. The students are encouraged to watch the films in English with English subtitles. Students are informed that the films are related to the chapter on weapons proliferation for the purpose of helping students comprehend the textbook. Once the films have been assigned for viewing outside of class, a short ten question quiz for each film is given in order to ensure that the students have watched the film.

The quizzes are primarily designed to verify viewing and to test general information about the plot. The quizzes are not intended to test knowledge of content related to the textbook. Once students have watched the films and taken the quizzes, instructors can conduct the lecture using the textbook. Because the section on small arms and light weapons as well as the proliferation of weapons is very short, the lecture should focus on the explanation of vocabulary words, key terms, and concepts. Throughout the lecture, the instructor should direct student attention to key passages and sections in the text that should be emphasized and highlighted.

After reviewing the material in the textbook, the instructor can proceed to show selected scenes from the film that address each of the characteristics of small arms and light weapons listed in the textbook (low cost; easy availability; lethality; simplicity and durability; portability and concealability; and dual usage). That is, when discussing the topic of "low cost" as a characteristic of small arms and light weapons, the instructors can use the scenes and scripts as detailed in the next section to illustrate and supplement the material in the textbook. This method of illustration using the films scenes and the reading of scripts should be repeated for each of the remaining characteristics as well as for the four reasons listed for the proliferation of weapons (superpower rivalry during the Cold War, military burden-sharing, regional balance of power, and global criminal activities). The method of teaching content related to small arms and light weapons and weapons proliferation are provided in the next section.

Finally, classroom discussions were conducted in order to examine the effectiveness of using films to improve communicative competence. After viewing scenes related to a specific topic, discussions were conducted to facilitate communicative competence related to course content. Some topics discussed in class included: the proliferation of weapons after the Cold War; the fate of Soviet weapons after the Cold War; the primary buyers of weapons; what constitutes the true weapons of mass destruction; the U.S. involvement in Afghanistan; the mujahedeen; Charlie Wilson's plan to assist the mujahedeen; the process of buying guns/arms in America; and the Second Amendment right to bear arms in America. 


\section{CLASSROOM APPLICATION}

\section{Teaching Content Related to Small Arms and Light Weapons}

The chapter in Global Issues (Payne, 2010) that deals with the proliferation of small arms and light weapons lists several characteristics that make them preferable such as: "low cost; easy availability; lethality; simplicity and durability; portability and concealability; and dual usage" (p. 129). The text provides a very brief description of each characteristic with few examples. While this may be sufficient for students who are familiar with the subject matter, students not familiar with the subject could benefit from additional information. The aforementioned characteristics of small arms and light weapons are examined below using the scenes and scripts from the films and documentary in order to demonstrate how films can help students better comprehend the key terms and concepts contained in the textbook.

\section{1) Low Cost}

In Charlie Wilson's War, Congressman Wilson and the Egyptian minister of defense discuss arrangements for the transfer of AK-47 assault rifles made in Soviet-licensed factories in Egypt for shipment to the mujahedeen in Afghanistan. They negotiate a price that is reasonable for both sides facilitating the sale. The conversation illustrates how the technological simplicity of the AK-47 and other small arms coupled with economies of scale lowers the manufacturing price of these weapons. These weapons are relatively inexpensive to produce because of economies of scale and their relatively low level of technological sophistication.

1) Charlie: You have Soviet-licensed factories that can put out Kalashnikovs at a rate of 25,000 a week?

2) Egyptian Defense Minister: That's correct.

3) Charlie: What about city warfare devices?

4) Egyptian Defense Minister: What kind?

5) Charlie: Bicycle bombs, limpet mines, plastic, tripwire mines?

6) Egyptian Defense Minister: Yes, yes. Whatever you need.

(Conversation 1, Charlie Wilson's War)

In Lord of War, Andre Baptiste, the dictator of Liberia, tells Yuri that he will not pay his asking price because there is no shortage of weapons in his country and that they are commonly available for sale at low cost on the street. 
Baptiste: I am not going to pay your asking price. We are not a rich people. And besides, the market is already flooded with your Kalashnikovs. Do you realize in some parts of my country, you can get one for the price of a chicken?

(Conversation 2, Lord of War)

\section{2) Easy Availability}

In Bowling for Columbine, Michael Moore opens a bank account in order to receive a free gun. Moore invests in a Certificate of Deposit that offers a free Weatherby firearm or other guns from a catalog. The only other requirement is for Moore to complete a criminal background check which is also done at the bank. After the criminal background check is cleared, Moore is presented with the firearm. He jokingly asks the viewers, "Do you think it's a little dangerous handing out guns in a bank?" The episode provides a comedic but realistic example of how relatively easy it is to obtain a firearm in America.

\section{3) Lethality}

All three of the films used in this article illustrate in visual detail the deadly nature of small guns and light weapons. In Bowling for Columbine, the mass shooting at Columbine High School showed the lethality of small arms and assault rifles used by the students in their cold and methodic shooting spree. Many students were killed and many more seriously injured. In Charlie Wilson's War, the mujahedeen uses small portable stinger missiles to shoot down advanced fighters jets and attack helicopters. They also use shoulder mounted missiles to destroy battle tanks. In Lord of War, the AK-47 is frequently shown in many of the battle scenes that depict the horrors of genocide, drug wars, and totalitarian dictatorships. But in one of the most poignant scenes in the film, Interpol agent Jack Valentine berets Yuri on the true nature of what he believes constitutes the real weapon of mass destruction.

Valentine: You get rich by giving the poorest people on the planet the means to continue killing each other. Do you know why I do what I do? I mean, there are more prestigious assignments . . keep track of nuclear arsenals. You'd think that's more critical to world security, but it's not. No, nine out of ten war victims today are killed with assault rifles and small arms like yours. Those nuclear missiles? They sit in their silos. Your AK-47? That is the real weapon of mass destruction.

(Conversation 3, Lord of War) 


\section{4) Simplicity and Durability}

In Lord of War, Yuri attributes the popularity of the AK-47 to its simplicity and durability. In one scene, Yuri describes the intricate details of the AK-47. His description of how children are able to use it as well as how it will work in any weather and field conditions reveal the simplicity and durability of the weapon. Yuri ironically notes that the AK-47 is the Soviet Union's "greatest export."

Yuri (V.O.): Of all the weapons in the vast Soviet arsenal, nothing was more profitable than Avtomat Kalshnikova, model of 1947 - more commonly known as the AK-47 or Kalashnikov. It's the world's most popular assault rifle - a weapon all fighters love. An elegantly simple nine pound amalgamation of forged steel and molded plastic. It doesn't break, jam or over-heat. It will shoot whether it's covered in mud or filled with sand. It's so easy, even a child can use it. And they do. The Russians put the gun on a coin. Mozambique put it on their flag. Since the end of the Cold War, the Kalashnikov has become the Russian peoples' greatest export - after that comes vodka, caviar, and suicidal novelists. One thing's for sure, no one was lining up to buy their cars.

(Conversation 4, Lord of War)

\section{5) Portability and Concealability}

In Lord of War, Yuri begins his career in arms dealing by selling Israeli made Uzi machine guns that are small, powerful, and easy to conceal. He is able to conduct and expand his business because the weapons are easy to conceal and transport. He makes note of how easy it is to pass the guns through airports, security checks, or national borders because they could be conveniently shipped in trucks or airplanes. He also comments on how easy the guns are to conceal in various electronic devices such as video cameras.

Yuri (V.O.): Fortunately, back then a video camera was as big as a bazooka. Yuri: Gentlemen. The new Uzi machine pistol. Big firepower in a small package. This little baby uses $9 \mathrm{~mm}$ hollow points. Twenty twenty-five round extendable mags . . . rear-flip adjustable sights. Silencer comes standard. Excellent recoil reduction. Muzzle jump reduced forty percent. Sixty percent improved noise suppression. You could pump a mag into me right now and never wake the guy in the next room.

(Conversation 5, Lord of War) 


\section{6) Dual Usage}

Small arms and light weapons are popular in many countries because they can be used by both the military and police forces. The weapons are also available to ordinary civilians. In all three films, small arms and light weapons, such as the AK-47, are popular with rebel groups, criminals, and terrorists. In Lord of War, Yuri is seen selling small arms and light weapons to members of ethnic conflicts, the mafia, drug lords, authoritarian dictators, terrorists, and to sovereign countries. In Charlie Wilson's War, the AK-47 is the primary weapon for both the Soviet army and the Afghan rebels. In Bowling for Columbine, small arms and light weapons are available and used by the military, police, and ordinary citizens.

\section{Teaching Content Related to Weapons Proliferation}

In addition to the proliferation of small arms and light weapons, there are strategic, economic, and political motivations for the proliferation of weapons. In Global Issues (Payne, 2010), the chapter on weapons proliferation lists eleven reasons for the proliferation of weapons. These include: superpower rivalry during the Cold War; military burden-sharing; regional balance of power; political, military, and economic influence; economies of scale; self-reliance; economic factors; ethnic conflicts; global criminal activities; and cultural values (p. 130). As in the description of small arms and light weapons, the textbook provides limited descriptions of a few lines of explanation for each factor. While sufficient for political science majors who have completed introductory courses related to the major, it may not be enough for students unfamiliar with political science, history, or international relations. Similar to the previous section, this section focuses on four of the eleven reasons provided to illustrate how the scenes and scripts from the films can be used to help students improve comprehension of the textbook.

\section{1) Superpower Rivalry During the Cold War}

During the Cold War, the United States transferred weapons to their NATO allies and the Soviet Union did likewise to the Warsaw Pact in order to establish a system of collective self-defense. This was one way in which the proliferation of weapons expanded to allies in Europe as well as other parts of the world including Asia. The fear of mutual assured destruction brought about because of nuclear weapons prevented the two superpowers from engaging in a direct confrontation. Instead, there were many proxy wars conducted in Korea, Vietnam, and Afghanistan with both superpowers supporting their allies. The United States engaged in a policy of containment to limit the spread of 
communism around the world. One aspect of containment was to provide economic and technical assistance to their allies. In Lord of War, Yuri presents a concise overview of the rivalry that existed between the Soviet Union and NATO. The buildup of weapons during the Cold War was unprecedented in scale but never used because of the fear of assured total annihilation.

Yuri (V.O.): Those forty-five years of mutual hatred between the East and the West had generated the highest weapons buildup in history. The Soviets had guns coming out of the demon hole. Huge stockpiles, and now no enemy.

(Conversation 6, Lord of War)

A common aspect in proxy wars regarding the supplying of arms and assistance to respective allies is illustrated in both Charlie Wilson's War and Lord of War. A combatant caught by the enemy cannot have in his possession arms provided by the host superpower because it could turn the Cold War into an actual war. Therefore, the covert transfer of arms by government or freelance arms dealers were required. In Charlie Wilson's War, Gust Avrakotos explains the predicament of supplying arms during the Cold War.

1) Gust: It's not that simple

2) Charlie: Why not?

3) Gust: Well, for one thing it's covert. When an Afghan freedom fighter gets captured, it can't be with an American-made weapon on him. That's how a cold war turns into an actual war, and that's something you want to keep a good eye on.

4) Charlie: So anything we give them has to look like it could have been plausibly captured from the Soviets.

5) Gust: Yeah, that's right.

6) Charlie: You know who's good at that?

7) Gust: Israel and Egypt.

8) Charlie: That's right.

(Conversation 7, Charlie Wilson's War)

The proliferation of weapons in Afghanistan during the Cold War rivalry is also revealed through the covert operations conducted by Charlie Wilson and Gust Avrakotos. With Joanne Herring's assistance, the three are able to mastermind a plan to supply the mujahedeen with arms in order to fight the Soviets. There are many obstacles to overcome in order for them to accomplish their goals. Wilson must convince key members of Congress to support his plan to increase funding to assist the Afghan rebels. Wilson must 
also convince Israel and Egypt to cooperate in his plan to manufacture and supply arms to the rebels. In the following conversation, Joanne summarizes Wilson's position and situation in Congress as they relate to their plan to assist the rebels and defeat the Soviets.

1) Charlie: Well, as a member of the Defense Subcommittee, did you think I wasn't aware that the Soviet Union's invaded Afghanistan?

2) Joanne: Yes, I believe my government is aware, but I was wondering if they were thinking of doing anything about it other than boycotting the Olympics, which I think you'll agree, was a fairly impotent response to the greatest national security threat we've faced since the Cuban Missile Crisis.

3) Charlie: Well, I don't think making more movies about it is gonna do the trick, if that's what you're asking.

4) Joanne: It's not. Exactly how much power do you have as a member of the Subcommittee?

5) Charlie: Which one? I'm on two.

6) Joanne: Foreign Ops.

7) Charlie: Eight members and myself hand out 11 billion in foreign assistance.

8) Joanne: And what about the Defense Subcommittee?

9) Charlie: Our budget is hidden.

10) Joanne: It's also unlimited.

11) Charlie: Yeah.

12) Joanne: Would you like to see my room?

13) Charlie: Yeah.

14) Joanne: So, unless I'm wrong, and that would be unusual for me, you sit at the intersection of the State Department, the Pentagon and the CIA. You meet in a soundproof room underneath the Capitol and you preside over a secret and unlimited budget for the three agencies you would need to conduct a covert war. Isn't that right?

15) Charlie: I also have seats at the Kennedy Center.

16) Joanne: Isn't that how you were able to double the CIA budget for black approps in Afghanistan just by saying so?

(Conversation 8, Charlie Wilson's War)

\section{2) Military Burden-Sharing}

During the Cold War and afterwards, the two superpowers and other countries with 
nuclear capabilities are reluctant to engage in direct military confrontation for fear of catastrophic losses. As a result, the superpowers and other nations provided their allies with arms and the technical assistance required to use, maintain, and repair their weapons. In addition, they provided the required technology to produce their own weapons in order to increase their ability to defend themselves. The transfer of weapons to American allies such as Japan, South Korea, and Taiwan was an example of the Nixon Doctrine.

In Charlie Wilson's War, Wilson wants to supply the Afghan rebels with the weapons necessary to defeat the Soviets. He visits the U.S. embassy in Pakistan in order to facilitate the transfer of weapons. Instead of cooperation, he is met with resistance from Harold Holt, the embassy station chief who tries to dissuade Wilson's plan to arm the Afghan rebels. Holt reiterates the need to maintain a low key posture with the Soviets in order to avoid a direct confrontation.

1) Charlie: Why ain't they shooting down them helicopters?

2) Holt: I'm sorry?

3) Charlie: The helicopters, Harold. Why ain't we giving them something to shoot down them helicopters?

4) Holt: The helicopters are a problem.

5) Charlie: You think?

6) Holt: Congressman ...

7) Charlie: They're shooting at Soviet gunships with Enfield rifles. That's basically what Davy Crocket used.

8) Holt: The Soviet Hind gunship is especially armor plated to resist bullets.

9) Charlie: Yeah, I know. So you tell me what you need to shoot them down?

10) Holt: What do you mean?

11) Charlie: Tell me what you need, and I will go about getting it for you.

12) Holt: Congressman, I appreciate your generosity, but a sudden influx of money and modern weaponry would draw attention.

13) Charlie: What?

14) Holt: A sudden influx of money and modern ...

15) Charlie: Wait, it would draw attention?

16) Holt: Yeah.

17) Charlie: Why, I don't even know what that means. This is the Cold War everybody knows about.

(Conversation 9, Charlie Wilson's War) 


\section{3) Regional Balance of Power}

Intricately connected to military burden-sharing is the need to maintain regional balance of power. The transfer and sale of arms to allies and other groups are often justified in order to maintain regional stability and diminish the possibility of a major conflict or war. In Charlie Wilson's War, Wilson wants to arm the Afghan rebels to neutralize Soviet aggression and their advance to the Persian Gulf. After concluding his talk with Harold Holt at the U.S. embassy in Pakistan, Wilson later has a conversation with Gust Avrakotos who details Holt's policy regarding the Soviet. As the conversation reveals, the purpose of arming the rebels is not to win the war but to prolong it in order to defeat the Soviets by attrition.

1) Charlie: Fifteen hours ago, I offered Harold Holt the keys to the safe, okay? I stood there in the office in Islamabad, and I said, "How much do you need?" And I was apparently annoying him.

2) Gust: Well, Harold Holt's a massive tool, Congressman. He's a cake-eater. He's a clown. He's a bad station chief. And I don't mean to cast aspersions on a guy, but he's gonna get us all killed.

3) Charlie: Really?

4) Gust: Yeah.

5) Charlie: Well, how does he expect to defeat the Soviets in Afghanistan without ... He said, "A sudden influx of money ...."

6) Gust: Yeah, an influx of money and new weaponry would draw attention. He's not trying to defeat the Soviets, Congressman.

7) Charlie: What the hell are you talking about?

8) Charlie: What do you mean, he's not trying to defeat the Soviets?

9) Gust: Well, he wants to bleed them. Payback for Vietnam. Make it so they just have to keep sending troops in, keep sending money, and troops, and money until they just go out of their fucking minds the way we did.

10) Charlie: You mean to tell me that the U.S. strategy in Afghanistan is to have the Afghans keep walking into machine gun fire till the Russians run out of bullets?

11) Gust: That's Harold Holt's strategy. It's not U.S. strategy.

12) Charlie: What is U.S. strategy?

13) Gust: Well, strictly speaking, we don't have one. But we're working hard on that.

14) Charlie: Who's we? 
15) Gust: Me and three other guys.

(Conversation 10, Charlie Wilson's War)

It is apparent that Holt's plan to "bleed" the Russians is the current U.S. policy in regard to the Soviet. The policy is to prolong the war as long as possible in order to inflict as much damage to the Soviets as possible in regard to military personnel and economic expenditure. The goal is therefore not to end the war.

In another scene, Wilson has managed to convince the Israelis to transfer arms to Pakistan in order for the Pakistanis to deliver the arms to the Afghan rebels. Because Israel and Pakistan are enemies, the political implications in regards to international relations is displayed in the conversation between Wilson and President Zia of Pakistan.

1) President Zia: You want me to go into business with the Israelis?

2) Charlie: Just for this one purpose, yes, Mr. President. The Israelis have the largest stockpile of Soviet-made weapons in friendly hands.

3) President Zia: I know that. I need to trust that this arrangement will remain secret. Pakistan and Israel would have to appear to be enemies in the public eye.

4) Charlie: Yeah, I don't think that's a tough sell.

(Conversation 11, Charlie Wilson's War)

\section{4) Global Criminal Activities}

Another major reason for the proliferation of weapons is associated with the globalization of terrorism, drug trafficking, smuggling, money laundering, and other criminal activities that require small arms and light weapons. In Lord of War, Yuri remarks how the Russian mafia also immigrated to America to conduct their criminal activities in Little Odessa. In an early scene in the film, Yuri coincidentally witnesses an exchange of gun fire between hired assassins and a Russian mobster.

Yuri (V.O.): Growing up in Little Odessa, murder was everyday part of life. Russian mobsters had also migrated from the Soviet Union and when they came to America, their baggage came with them. There was always some gangster getting whacked in my neighborhood.

(Conversation 12, Lord of War)

After witnessing the shootout between the Russian mobster and hit men, Yuri gets the inspiration to become an arms dealer. He begins his trade by selling arms primarily to 
criminals engaged in drug trafficking, smuggling, and money laundering. Eventually, Yuri sells guns to drug lord, warlords, and paramilitary soldiers involved in ethnic conflicts. It is apparent that Yuri will sells arms to anyone who has the financial means to pay for them. He does not take sides nor does he let his conscious get in the way of his business transactions. In a voice over, Yuri explains his views and attitude in regard to his arms business.

Yuri (V.O.): Selling guns is like selling vacuum cleaners. You make calls, pound the pavement, take orders. I was an equal opportunity merchant of death. I supplied every army but the Salvation Army. I sold Israeli-made Uzis to Muslims. I sold communist made bullets to fascists. I even shipped cargo to Afghanistan when they were fighting my fellow Soviets. I never sold to Osama Bin Laden, not on any moral grounds. Back then, he was always bouncing checks. By the mid-'80s my weapons were represented in eight of the world's top ten war zones.

(Conversation 13, Lord of War)

Yuri's primary reason for entering the arms trafficking business is to make money. This is perhaps the main reason for the global proliferation of weapons. Whether conducted by a freelancer like Yuri or countries such as the United States, the sale of weapons is a multibillion dollar industry that contributes to the worldwide increase of weapons. As such, Yuri's view of warlords and dictators as well as his methods to ensure receiving payment is reflected in the following voice over.

Yuri (V.O.): The second rule of gunrunning is: Always ensure you have a foolproof way to get paid, preferably in advance, ideally to an off-shore account. That's why I chose my customers so carefully. Say what you like about warlords and dictators, they tend to have a highly developed sense of order. They always pay their bills on time.

(Conversation 14, Lord of War)

The transfer of profits from arms sales to offshore and foreign bank accounts is an interesting topic that can be discussed in addition to the proliferation of weapons. Money laundering and the use of commodities, such as diamonds, to finance arms deals can also be discussed in regard global criminal activities. 


\section{RESULTS AND ANALYSIS}

Appendix A shows the responses to the eighteen questions that examine the effectiveness of using films to teach aspects of weapons proliferation in the EAP classroom. The students responded above average $(M=3.00)$ on all of the questions. Based on the results from the survey, the use of films to teach weapons proliferation was very effective. As detailed below, students revealed that the films increased their ability to comprehend the textbook and understand the technical terms related to the course material.

In regard to improving reading comprehension, students responded by asserting that films: make the learning process easier than by only reading the textbook $(M=4.15)$; make the learning process more entertaining and enjoyable $(M=4.21)$; are a useful tool for getting students interested in their subject $(M=4.18)$; make students learn more vocabulary and technical terms related to the contents of international relations and weapons proliferation $(M=3.82)$; helps to broaden understanding of the contexts regarding international relations and weapons proliferation $(M=3.97)$; improves reading skills by increasing my own previous knowledge related to international relations and weapons proliferation $(M=3.65)$.

In regard to listening skills, films proved effective by: increasing listening skills through various features of spoken language, such as vocabulary awareness, pronunciation, accent, speech pace, and tone $(M=3.74)$; increasing listening skills through exposure to colloquial language which is not "textbook" language $(M=3.97)$; improving listening comprehension by enhancing the images presented in the films $(M=4.09)$.

The survey also determined that the use of films was effective in improving communicative competence by: assisting to debate subject matter $(M=3.91)$; helping to discuss international relations and weapons proliferation by providing students with examples of certain situations used in "real" situations $(M=4.03)$; and promoting the exchange of a wide variety of ideas through creative and critical thinking $(M=3.76)$.

The survey also found that films were effective by helping students with their writing by: assisting to write about the subject matter $(M=3.97)$; helping when writing essays related to international relations and weapons proliferation WP $(M=3.94)$; and promoting creative and critical aspects related to international relations and weapons proliferation $(M$ 3.79).

And finally, films were effective in making the course more interesting and enjoyable by: increasing participation in more film-related activities in a reading course $(M=4.47)$; improving communicative competence through films that satisfy my academic needs $(M$ $=4.18)$; and improving my language knowledge as well as content knowledge $(M=4.21)$.

The use of films and documentaries may have also improved communicative competence by activating background knowledge and experience. As mentioned earlier, 
classroom discussions are another form of background knowledge or experience that encourages students to engage in interaction to promote analysis, reflection, and critical thinking (Goldenberg, 1992). As reflected in the survey, films increased interest in the class and created a more conducive environment for learning to take place by allowing students to use and contribute their own experience and knowledge. As Lei et al. (2010) note, background knowledge or experiences are non-reading experiences that college instructors can use to facilitate and maximize students learning new materials.

In Korea, college students are often reluctant to engage in classroom discussions, even more so if done in English. When effectively conducted, class discussion can spur creative and critical thinking as well as encourage students to participate. Class discussions can also stimulate students to listen and evaluate the material being discussed while giving them the opportunity to bring up their own thoughts and ideas (Lei et al., 2010). Classroom discussions can therefore clarify the information in the textbooks as well as help students connect key terms and theories with historical events and actions. For instance, though most students do not have much knowledge related to weapons proliferation, class discussions revealed that a surprising number of student were very familiar with small arms and light weapons. This may be attributed to the popularity of computer games in Korea that simulate war games and scenarios. Both male and female students were familiar with the AK-47 and the Uzi because of computer games such as Sudden Attack, Call of Duty, and Medal of Honor that utilize a variety of conventional arms and weapons. The awareness of these weapons facilitated a familiarity with the small arms and light weapons mentioned in the course textbook and in the movies. The activation of background information and experience coupled with the use of films enabled students to better comprehend the course material.

\section{CONCLUSION AND IMPLICATIONS}

This article examined the use of films to teach topics related to the issue of weapons proliferation in the EAP classroom. The rationale for this approach is based on the premise that content knowledge and communicative competence need to be improved in classes that are taught in English in Korea. In large classes with only a midterm and final exam, instructors may not be able to ascertain whether poor student performance is based on low motivation or whether students had difficulty comprehending the course textbook. Instructors should take this issue into consideration when preparing and conducting lectures. If the reason for poor performance is due to a lack of English proficiency and below average comprehension skills, supplemental forms of instruction are required when teaching content courses. 
Because films are a text from popular culture, students enjoy using them more than textbooks in the classroom. In addition to the benefit of increased interest, films can be used to supplement and illustrate content included in textbooks. The films help students understand the characteristics of small arms and light weapons and the reasons for the global proliferation of weapons. The films used in the course are based on actual events and are applicable to the issues discussed in the textbook. The films also provide a visual text for students to apply what they have learned. The films and documentary therefore are supplemental resources that help students with their content knowledge as well as improve their communicative competence.

Though films can be a powerful supplement in the EAP classroom, particular attention must be paid to differentiate between entertainment and educational aspects of using films. Even in films that are based on true stories such as Lord of War and Charlie Wilson's War, the instructor should help students understand the difference between artistic license and what the facts are as related to the issues and topics presented. Likewise, students must be made aware that even a documentary, such as Bowling for Columbine, is the product of an artist who is presenting his/her views on a particular topic and that it should not be viewed as objective truth.

Though this study focused on one chapter of a textbook on global issues, the methodology can be applied to other chapters of the course textbook as well. The methodology detailed in this study was applied in the course, Contemporary Political Discourse, for the past three years. Students performed well on the sections that dealt with weapons proliferation on the written exams. However, the good performance may have been the result of more time being spent on the chapter. In addition, the results of the survey are based on a small sample size with no control group to make a comparison. This was unavoidable because most courses in the global program average between fifteen to twenty students per class and because only one section of the course is offered per year. Therefore, the data from two years was combined. Subsequent research with a larger sample and control group may be conducted to further test the results of this study. Lastly, the statistical support regarding the advantages of using films and documentaries were mainly dependent on student's opinions through a survey that suggests a lack of reliability and generalization. To resolve this discrepancy, further study should be conducted to examine the actual development of students' communicative competence by employing more valid methods such as a pre-test and post-test, experimental group and control group.

\section{REFERENCES}

Centellas, M. (2010). Pop culture in the classroom: American idol, Karl Marx, and Alexis 
de Tocqueville. PS: Political Science \& Politics, 43(3), 561-565.

Choi, J. (2007). Teaching literature through the comparison of the original text with film adaptations: In case of The Great Gatsby. The Journal of Teaching English Literature, 11(2), 129-149.

Engert, S., \& Spencer, A. (2009). International relations at the movies: Teaching and learning about international politics through film. Perspectives, 17(1), 83-103.

Fitzgerald, F. S. (2018). The great Gatsby. New York, NY: Scribner.

Goldenberg, C. (1992). Instructional conversations: Promoting comprehension through discussion. The Reading Teacher, 46(4), 316-326.

Goldenberg, M., Lee, J. W., \& O'Bannon, T. (2010). Enhancing recreation, parks, and tourism courses: Using movies as teaching tools. Journal of Hospitality, Leisure, Sport \& Tourism Education, 9(2), 4-16.

Kim, J. (2003). English literature and film: A case study. The Modern English Society of Korea, 47(1), 45-65.

Kim, K. (2013). Using video in the English literature classroom: Literary analysis, theology, Cain, and Kung Fu. STEM Journal, 14(3), 1-18.

Kim, K. (2016). Teaching cultural theory in the EAP classroom using Disney Pixar's Cars. STEM Journal, 17(2), 1-23.

Koch, G., \& Dollarhide, C. T. (2000). Using a popular film in counselor education: Good Will Hunting as a teaching tool. Counselor Education and Supervision, 39(3), 203211.

Kuzma, L. M., \& Haney, P. J. (2001). And... action! Using film to learn about foreign policy. International Studies Perspectives, 2(1), 33-50.

Lee, H. (2001). How to use film in English literature courses. The Journal of Literature and Film, 2(1), 27-51.

Lei, S. A., Rhinehart, P. J., Howard, H. A., \& Cho, J. K. (2010). Strategies for improving reading comprehension among college students. Reading Improvement, 47(1), 3042.

Macy, A., \& Terry, N. (2008). Using movies as a vehicle for critical thinking in economics and business. Journal of Economics and Economic Education Research, 9(1), 3151.

Moore, M. (Director). (2002). Bowling for Columbine [Motion picture]. United States: United Artists, Metro-Goldwyn-Mayer.

Muller, V. (2006). Film as film: Using movies to help students visualize literary theory. English Journal, 95(3), 32-38.

Niccol, A. (Director/Producer), \& Cage, N. (Producer). (2005). Lord of war [Motion picture]. United States: Lionsgate Films.

Nichols, M. (Director), \& Hanks, T. (Producer). (2007). Charlie Wilson's war [Motion 
picture]. United States: Universal Pictures.

Payne, R. J. (2010). Global issues ( $3^{\text {rd }}$ ed.). New York, NY: Pearson.

Pescosolido, B. A. (1990). Teaching medical sociology through film: Theoretical perspectives and practical tools. Teaching Sociology, 18(3), 337-346.

Pino, N. W., Brunson, R. K., \& Stewart, E. A. (2009). Using movies to illustrate ethical dilemmas in undergraduate criminal justice classes. Journal of Criminal Justice Education, 20(2), 194-202.

Sealey, K. S. (2008). Film, politics, and education: Cinematic pedagogy across the discipline. New York, NY: Peter Lang.

Seo, E. (2016). Learning history and sociocultural issues through Woman in Gold. STEM Journal, 17(2), 47-63.

Shih, M. (1992). Beyond comprehension exercises in the ESL academic reading class. Tesol Quarterly, 26(2), 289-318.

Shin, S. (2000). Teaching English and American literature/culture in the age of digitalization. The Journal of Teaching English Literature, 4, 5-35.

Stoddard, J. D., \& Marcus, A. S. (2010). More than "showing what happened": Exploring the potential of teaching history with film. The High School Journal, 93(2), 83-90.

Sung, K. (2000). The use of film texts in American novel class. The Journal of Literature and Film, 1(1), 97-117.

Swimelar, S. (2013). Visualizing international relations: Assessing student learning through film. International Studies Perspectives, 14(1), 14-38.

Waalkes, S. (2003). Using film clips as cases to teach the rise and "decline" of the state. International Studies Perspectives, 4(2), 156-174.

Weber, C. (2001). The highs and lows of teaching IR theory: Using popular films for theoretical critique. International Studies Perspectives, 2(3), 281-287.

Yim, J. (2004). A pedagogical search for teaching American culture through American literature. The Journal of Teaching English Literature, 8(1), 147-167.

\section{APPENDIX A}

Means and Standard Deviations of Questionnaire

\begin{tabular}{llcc}
\hline \hline & \multicolumn{1}{c}{ Questions } & $M$ & $S D$ \\
\hline 1 & Films make the learning process easier than by only reading the textbook. & 4.15 & .82 \\
\hline 2 & Films make the learning process more entertaining and enjoyable. & 4.21 & .98 \\
\hline 3 & Films are a useful tool for getting students interested in their subject. & 4.18 & .67 \\
\hline 4 & $\begin{array}{l}\text { Films promoted me to learn more vocabulary and technical terms related } \\
\text { to the topic of Weapons Proliferation in a natural situation. }\end{array}$ & 3.82 & .87 \\
\hline
\end{tabular}


The Effectiveness of Using Films and Documentaries in the EAP Classroom to Teach Contemporary Political Discourse

\begin{tabular}{lllc}
\hline 5 & $\begin{array}{l}\text { Films helped me to broaden my understanding of the contexts (ex. low } \\
\text { cost; easy availability; lethality; simplicity and durability; portability and } \\
\text { concealability; and dual usage) regarding Weapons Proliferation. }\end{array}$ & 3.97 & .94 \\
\hline 6 & $\begin{array}{l}\text { Films improved my reading skills by increasing my own previous } \\
\text { knowledge related to Weapons Proliferation. }\end{array}$ & 3.65 & .88 \\
\hline 7 & $\begin{array}{l}\text { Films increased my listening skill through various features of spoken } \\
\text { language, such as vocabulary awareness, pronunciation, accent, speech } \\
\text { pace, and tone. }\end{array}$ & 3.74 & .90 \\
\hline 8 & $\begin{array}{l}\text { Films increased my listening skill through exposure to colloquial } \\
\text { language which is not "textbook" language. }\end{array}$ & 3.97 & .80 \\
\hline 9 & $\begin{array}{l}\text { Listening comprehension can be enhanced by the images presented in the } \\
\text { films. }\end{array}$ & 4.09 & .83 \\
\hline 10 & $\begin{array}{l}\text { Films assisted me to debate the subject matter by developing my } \\
\text { comprehension of abstract theories and concepts related to course } \\
\text { materials. }\end{array}$ & 3.91 & .87 \\
\hline 11 & $\begin{array}{l}\text { Films helped me to discuss Weapons Proliferation by providing me with } \\
\text { examples of certain situations used in 'real' situations. }\end{array}$ & 4.03 & .90 \\
\hline 12 & $\begin{array}{l}\text { Films promoted me to exchange a wide variety of ideas through creative } \\
\text { and critical thinking regarding the proliferation of weapons in authentic } \\
\text { situations. }\end{array}$ & 3.76 & .92 \\
\hline 13 & $\begin{array}{l}\text { Films assisted me to write the subject matter by developing my } \\
\text { comprehension of abstract theories and concepts related to course } \\
\text { materials. }\end{array}$ & 3.97 & .72 \\
\hline 14 & $\begin{array}{l}\text { Films helped me to write an essay regarding Weapons Proliferation by } \\
\text { providing me with examples of certain situation used in 'real' situations. }\end{array}$ & 3.94 & .78 \\
\hline 15 & $\begin{array}{l}\text { Films promoted me to write a wide variety of ideas through creative and } \\
\text { critical thinking regarding the proliferation of weapons in authentic } \\
\text { situations. }\end{array}$ & 3.79 & .77 \\
\hline 16 & \begin{tabular}{l} 
I want to take part in more film-related activities in a reading course. \\
\hline 17
\end{tabular} & $\begin{array}{l}\text { Improving communicative competence through films satisfied my } \\
\text { academic needs. }\end{array}$ & 4.47 \\
\hline 18 & $\begin{array}{l}\text { After finishing this course, I improved my language knowledge as well } \\
\text { as content knowledge. }\end{array}$ & .66 \\
\hline & .80 \\
\hline
\end{tabular}

Applicable level: college

Keywords: EAP, films, content comprehension, communicative competence, weapons proliferation

Kim, Kitai

The Linton School of Global Business

Hannam University

70 Hannam-ro, Daedeok-gu, Daejeon 34430, Korea

E-mail: kitaikim@hnu.kr 
Received: September 30, 2018

Revised version: November 9, 2018

Accepted: Novembert 25, 2018 